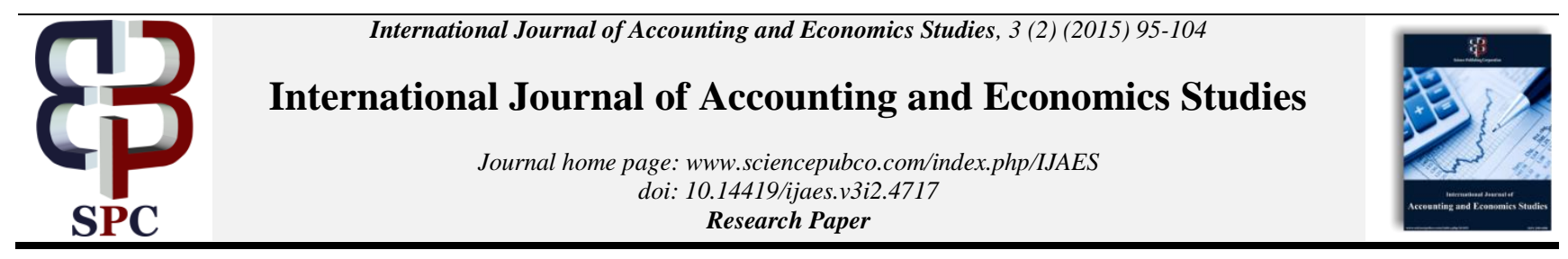

\title{
Book-tax differences: relevant explanatory factors
}

\author{
Rakia Riguen Koubaa*, Jarboui Anis \\ Department of Financial and Accounting, Universities Higher Institute of Business Administration (ISAAS), Tunisia \\ *Corresponding author E-mail:rakiariguen@yahoo.com
}

\begin{abstract}
This research is designed to investigate factors affecting the book-tax gap in the Tunisian context. Despite the close link between financial and tax accounting in Tunisia, it has been discovered that accounting, and taxation appear to diverge considerably. Regression analysis results highlight that this reporting gap is largely attributable to legal differences between financial and tax accounting as well as to discretionary earning management practices. Noteworthy, the study under takes to examine several factors that constitute the basis on which previously elaborated researches to have been based, and, which appear to be consistent with the present work particular context. Relying on an eight-year database, relevant to the period 2005-2012, the major factors affecting the book tax gap in Tunisia turn out to be profitability, sales growth, discretionary accruals, price to earnings ratio and debt.
\end{abstract}

Keywords: Book-Tax Differences; Institutional Factors; Non-Institutional Factors.

\section{Introduction}

Accounting and taxation are two autonomous regulations, sharing similar concepts while serving different purposes. Economically, accounting helps provide information on whether a company's activity is profitable or not. It serves a major purpose of defining the balance sheet account and statement. In this way, accounting turns out to be a remarkable business control instrument and decision support tool greatly useful for helping in investment, borrowing and hiring procedures. Inversely, however, tax laws are primarily devised to fulfill the primary aim of raising government funds or revenues (Mills and Neweberry, 2002). In addition, they are used as a mechanism for running government economic and social policy. Hence, a divergence between accounting and taxable income might well be recognized.

Book-tax differences (BTDs) have made a major subject of study for a considerable number of literary works. Worth mentioning, in this respect, are Passamani and al. (2014), who state that BTDs involve various aspects, mainly, the motives lying behind these differences, the potential interest conflicts stemming from an agency theory respective and the information quality disclosed to the market. In the recent accounting scandals, according to Halon (2005), however, the recently occurring accounting scandals have helped highlight the fact at BTDs stand as an indicator of poor financial reporting quality. In addition, several conducting academic studies have investigated the divergence between accounting and taxable income as a signal of earnings management. Most important among these differences figure, mainly, important information regarding earnings growth and persistence (Lev and Nissim, 2004; Halon, 2005), changes' effects on accounting methods (Seidman, 2010) and tax planning (Mills, 1998; Desai and Dharmapala, 2006; Wilson, 2009). Indeed, monitoring and recognizing earnings and tax management are often considered a critically important process of evaluating earnings quality and revealing manager's opportunistic behavior.
In this respect, some elaborated studies have demonstrated that BTDs do actually appear to reflect certain earnings management practices (Mills and Newberry, 2001; Phillips and all, 2003; Halon, 2005), while other studies consider such differences to be associated with tax shelters (Shelvin, 2001; Mggill and Outslay, 2004; Wilson, 2009; Frank and all, 2009).

Several researches pertaining to the relevant literature highlight that BTDs result mainly from discretionary earnings management as well as tax management practices (Mills and Newberry, 2001; Philips and all, 2003; Joos and all, 2003; Philips and all, 2004; Dunbar and all, 2004; Desai and Dharmapala, 2006; Tang and Firth, 2011; Frank and all, 2009; Wilson, 2009; Goncharov, 2009), along with non-discretionary practices explained by the differences persisting between accounting and tax rules. In this context, Long and all, (2013) also stipulate that the institutional differences refer to the normal BTDs originating from the accounting and tax regulations' inconsistency on calculating the income. Besides, some other non-institutional differences appear to prevail, denoting differences between accounting and taxable income emanating from other factors (as will be discussed later). Thus, the present research is conducted with the aim of underlining the major sources leading to the emergence of BTDs within the Tunisian context.

The present study might well constitute a contributing to the existing works conducted in this research area in several ways. On the one hand, it provides an extension to the previously elaborated literature, by treating the special context of Tunisia. Then, this research is considered as a new setting regarding which the analysis of BTDs' determinants is considered a very recent development and innovative undertaking. On the other hand, this work serves as an implementation framework, through an investigation study carried out with respect to information reflected in regard of BTDs.

Based on a sample composed of 28 Tunisian firms, observed over the period 2005-2012, the reached results reveal that sales growth, discretionary accruals, debt, price-to-earnings ratio and profitabil- 
ity turn out to be significantly related to BTDs, level, indicating that these factors prove to play an important role in mitigating information asymmetry.

The remainder of this paper is organized as follows: section 2 is devoted to describing the relevant definition and the BTDs pertaining research works, along with the previously elaborated literature reviews and hypotheses' development. As for section 3, it is dedicated to expose the applied methodology, while section 4 contains the empirical results evaluation notes. Ultimately, section 5 bears the concluding remarks and paves the way for future research perspectives.

\section{Literature review}

This section is reserved to provide an explanation of the BTDs concept, i.e., the relationship between financial and tax reporting in Tunisia, along with a review of previous literature in a bid to develop our advanced hypotheses.

\subsection{Book-tax differences}

According to Tang (2006), BTDs refer to the gap between pre-tax incomes, as reported in a company published financial statement (thereafter book income), and the taxable incomes reported to tax authorities. Tax and financial reporting are separate, though inter related, accounting systems with distinct objectives (Plesko, 2000).

Noteworthy, however, a certain connection is tolerated to persist between taxation and accounting. Indeed, taxable income is usually determined in terms of accounting income which, in turn, depends highly on the taxation rules. Yet, this connection is not always totally perfect owing to persisting divergences prevailing between both disciplines; hence, extra accounting reprocessing seems often imposed.

A major means whereby company results can be measured is accounting, through identification of economic flows and elaboration of financial statements. It helps describe and specify the firm's financial position assets' statement as well as performance throughout the current period. As a tax regulation mechanism, accounting aims at determining the tax base and taxation methods' valuation principles. Accounting and taxation are two disciplines, which, though autonomous, they might be, have important common areas and intermingle remarkably. It is worth highlighting that in Tunisia; taxation has greatly contributed in developing the accounting area, in such a way as the accounting/taxation convergence turns out to provide a favorable context for both fiscal and accounting areas to flourish. Since the publication of the Tunisian corporate accounting system in 1996, certain tax rules have evolved towards reconciliation with the accounting rules; still, this influential trend remains limited in scope. Despite these similarities, noticeable differences between accounting and taxation do actually prevail. In fact, each of the tax and accounting laws responds exclusively to a different standard-setting process. Indeed, while the fiscal rules are primarily based on the principle of legality (tax cost model, acquired debts and certain liabilities), the accounting rules are devised and used basically for information purposes. The latter entail greater flexibility. Besides, financial accounting aims at satisfying investors' at risk priority needs of (shareholders and lenders), where as taxation stands as an instrument of economic policy and a wealth regulatory mechanism among the various actors.

Ultimately, taxable income determination rests heavily on accounting information, and it is obvious that differences between accounting and taxation do certainly prevail.

Regarding the Tunisian context, such as distinctive differences may well result from the fact that certain expenses are being rejected by taxation (e.g., fines and penalties), certain products being exempt from taxation (e.g., dividends received), unaccepted accounting treatments by tax departments (e.g., impairment, discounting receivables, etc.), income and expenses' exercise at- tached rules, time lag (e.g., provisions, subsidies and exchange differences). Still both permanent and temporary differences do actually predominate between both disciplines. In fact, the permanent differences, stemming from different conception permanent items, contribute directly in affecting calculation of income tax expenses and, therefore, influence the current post-tax earnings (Tang, 2006). As for the temporary BTDs, they are usually generated by deferred tax expenses.

Some U.S. studies (e.g., Manzon and Plesko, 2002; Mills, Newberry and Novack, 2003; Plesko, 2004) have discovered that aggregate BTDs trend to increase noticeably over the year 1990, and that this growth cannot be exclusively explained by mere institutional determinant factors only but, also by other non-institutional factors. According to Long and all. (2013), institutional differences, in such a context, refer to the normal BTDs resulting, simultaneously, from accounting and tax regulations' inconsistency on calculating income; whereas, non-institutional differences denote differences occurring between the accounting and the taxable income engendered by other factors to be discuss in the upcoming section.

\subsection{Hypotheses development}

This study is actually intended to highlight and elaborate on two major sets of assumptions. The first of these sets relate to institutional factors enclosing factors that pertain to differences between accounting regulations and tax rules. Regarding the second series set, it involves the non-institutional factors that constitute the opportunistic information emanating from the managerial choices in regard of accounting and tax reporting.

\subsubsection{Institutional factors}

With respect to the first hypotheses' series, three major factors have been selected based on previously elaborated research works, that sound to consistent with our context, namely: profitability, sales growth and investment growth.

\section{- Profitability}

According to Manzon and Plesko (2002), profitable companies can effectively apply the tax deductions and tax credits to benefit from tax exemptions. Indeed, in beneficiary firms, managers usually appeal to these tax benefits in a bid to reduce the amount of taxable incomes; thus, widening the differences between accounting and tax results (Sodan, 2012). In fact, on examining a sample consisting of 17,692 observations, studies over the period 19881999, the authors have discovered a positive and significant relationship persisting between profitability and BTDs. Other already conducted research works suggest that the highly profitable firms most often enjoy highly effective cash tax rebates as well as remarkable levels of BTDs (Khurana and all, 2009). They have come to the conclusion that the highly profitable firms generally enjoy higher long-run effective cash tax rates and greater permanent BTDs. At this level, the following assumption can be formulated:

H1: A positive relationship persists between profitability and BTDs.

\section{- Sales growth}

Sales growth constitutes a key factor in accruals' predicting models. Worth mentioning, in this respect, the modified Jones model (1991), which frequently applies such a variable. In turn, Tang and Firth (2011), Martina and al. (2011) As well as Manzon and Plesko (2002) have highlighted the prevalence of a positive relationship between sales growth and BTDs. They state clearly that: "growing firms may make more significant investments in taxfavored assets that generate timing differences in the recognition of expenses for financial reporting and tax purposes." In this respect, Kolay and al. (2011) have discovered that growth firms may have more discretion in accounting procedures as compared to a firm with stable revenue. Relevant literature stresses that larger firms tend to exhibit more BTDs and that rapidly growing firms 
usually have more BTDs' generating investments (Khurana and all, 2009).

Regarding the Tunisian context, sales growth may well lead to enormous credit losses. In financial reporting, these receivables are immediately recognized to stand as losses. Consequently, they lead to reducing the annual income and, subsequently, reducing the income tax expenses. Inversely, however, during tax reporting, these receivables are deductible from the taxable amount providing certain conditions are met. Such treatment differences may likely well create remarkable differences between the accounting income and the taxable one. These arguments lead to develop the hypothesis below:

$\mathrm{H}$ 2: A positive relationship prevails between sales growth and book-tax differences.

- Investment growth

Ever since the corporate accounting system publication, certain tax rules have evolved towards reconciliation with the accounting rules, even though this development is too limited. In fact, such a limitation has its explanation in the partial application of published accounting standards, due mainly, to the predominance of tax rules.

Devised by a World Bank team, the Report on the Compliance with Standards and Codes (ROSC) states that "preparers of financial statements of small and medium-sized businesses and public interest entities tend to follow the tax governed, rather than the accounting treatment recommended by the Tunisian accounting standards in several areas (depreciation, accounting relived, provisions). Transparency suffers from the predominance of tax considerations and differences arising in relation to the applicable accounting standards." By way of example, one could mention the treatment of the tangible fixed-asset depreciations' differences. According to the Tunisian accounting standard, the observation of tangible fixed assets' depreciation is mandatory. At tax level, however, no deduction is allowed, which involves negative divergences between the accounting income and the taxable one. In this regard, Manzon and Plesko (2002) have discovered a positive relationship to prevail between investment growth and BTDs. Besides, Tang and Firth (2011) apply this variable to capture the investment scale growth effect on BTDs relating to mechanical depreciation and amortization. They claim that investment growth is likely to help increase the provision for fixed and intangible assets' impairment provisions in the income statement appear as required under existing accounting standards. Under the Chinese tax laws, however, they are non- deductible, which would lead to a higher (lower) taxable income as compared to the earlier (later) years' book income. In addition, Kolay and all. (2011) underline the fact that gross PP\&E and net to gross PP\&E constitute timing BTDs. In fact, firms with more PP\&E assets are likely to have more discretion when accounting for depreciation and assets' book value. They also have more discretion when applying a certain book value asserting method (e.g., straight-line depreciation) any of the tax accounting available approaches (for instance, instance relevant to accelerated depreciation). Such a prediction leads to the formulation of the following hypothesis:

H3: A positive relationship exists between investment growth and book-tax differences.

\subsubsection{Non-institutional factors}

In this particular context, three non-institutional factors have been selected namely: discretionary accruals, the price-to-earnings ratio, institutional ownership and liquidity.

- Discretionary accruals

Over the recent decades, two major recurrent themes have been exhaustively treated in the accounting literature, namely: earnings management and BTDs. The great deal of empirical research works relevant to this area might well have their explanation in the pertinence of information concerning these two issues (Shackelford and Shevlin, 2001; Hanlon and Heitzman, 2010; Graham and all. 2012).More recently, however, the accounting area has exhibited a great request for improving the long prevailing accounting standards for the sake of providing more effectively useful data likely to help shareholders and stakeholders to reach the most efficient decisions. In this regard, such as precepts based norms might well serve to offer managers greater flexibility, to make the most appropriate evaluation judgments in such a way as to account for the economic effects of the activities undertaken by the organization. In addition, a higher flexibility of accounting standards reflects well a compromise reached with respect to contemporary achievements. In effect, while such flexibility is aimed at further promoting accounting information quality, it serves to enable the leader to take decisions that do not necessarily reflect the company reality, but rather a reality that he would intend to attain. Thus, the manager makes appeal to discretionary practices by managing earnings with the aim of manipulating accounting information in compliance with a certain economic incitation.

By way of hypothesis, BTDs are considered liable to be partly explained by the opportunistic practices implemented by earnings management oriented firms. Indeed, managers are often enticed to deliberately increase accounting earnings while reducing taxable income. Such a manipulation might well lead to increasing BTDs. Noteworthy, however, the finding published by Phillips, Pincus and Rego (2003) have indicated the persistence of a certain relationship between earnings management and BTDs. Furthermore, on examining whether BTDs are closely linked to earnings management and tax management practices, with respect to Chinese's firms' context, Tang and Firth (2011) attained, results appear to highlight that the earnings management practices could in part provide an explanation on the amount of such differences. As for Bouaziz and Omri (2011), they have also revealed the predominance of a significantly positive association between the current discretionary accruals and BTDs within the Tunisian context. Consequently, our pertinent hypothesis turns out to be:

H4: A positive relationship persists between discretionary accruals and BTDs.

- The price-to-earnings ratio

Several research works have been focused on analyzing stock market performance via application of various financial ratios, among which one can cite: the price-to-earnings ratio, the price-tsales ratio, the price-to-dividend ratio and the book-to-market ratio (Bodie and all, 2005). Most researchers analysts, managers and investors, however, rely heavily on the price- to-earnings ratio when analyzing the equity relative attractiveness, and use it as a technical assessment mechanism, whereby the individual stocks', sectors' and markets' performance can be evaluated (Molodovsky, 1953). According to Shen (2000), investors and analysts have long used the price-to-earnings ratio to help determine whether the extent to which individual shares are reasonably valued, i.e., this ratio may stand as the speculation means put at the investors' disposal to maintain stand growth through future profits. The priceto-earnings ratio represents an index of market-based assessment. As a ratio between the company share price and its earnings per share, this ratio is considered as a convenient determinant of BTDs. In particular, Long and all. (2013) have found a negative relationship between the price-to- earnings ratio and the book-tax gap. Once the ratio is proven to be high, the divergence extent becomes smaller. On the one hand, this denotes that the market has a clear inhibition effect on the company discrepancies. On the other hand, it signifies well that the market is well disposed to interpret the implication of information available within the accounting-tax differences, while considering that companies are actually witnessing noticeable discrepancies between accounting and taxable income, due to severe earnings manipulation thus providing them with the necessary feedback. In this respect, Khurana and all. (2009) have indicated that high-growth expecting firms' proxy determined, through market-to-book ratio, generally maintain lower long-run cash effective tax rates and, then, witness fewer permanent BTDs. In this way, the following assumption might well be posed:

H4: A negative relationship prevails between price-to-earnings ratio and book-tax differences.

- Institutional ownership 
The previously elaborated research works dealing with institutional investors have focused mainly on the latter's proper role in affecting investment decisions and stock prices. Only recently, however, has research begun to examine the institutions' role in corporate governance (Moser and all, 2012). In fact, Moore (2012) has highlighted both positive and negative BTDs' effects on environmental information. In conformity with Comprix and all. (2011) conducted studies, researchers connecting BTDs to such costs attribute their findings to a larger book-tax gap, incurring a negative effect on the financial statements' information quality and accuracy. Indeed, accounting-tax differences constitute an interesting instance whereby governance effects on managerial reporting decisions can be examined, partly because they contain information pertaining to several management accounting decisions and uncertainty surrounding them. Besides, some previously conducted studies have documented a diversity of various governance aspects' effects on specific managerial accounting decisions, as reflected in BTDs. Several among these studies do actually confirm the presence of a negative relationship between governance and earnings management (e.g., Cornett and all, 2008; Chung and all, 2002; Klein, 2002; Beasley and all, 2000; Dechow, Sloan and Sweeney, 1996; Beasley, 1996). On the contrary, however, some institutional investors appear to effectively monitor and discipline managers in an attempt to ensure that they maximize long-term value (Shleifer and Vishny, 1997). As for Monks and Minow (1995), they argue that investors with a long-term horizon seem to have strong incentives to monitor management in such a way as to ensure that it is acting in respect of the firm best interest. Other studies appear to provide conflicting data as to governance impact on tax planning as a major source of BTDs (e.g., Lanis and Richardson, 2011; Minnick and Noga, 2010; Khurana and Moser, 2012). Indeed, these authors indicate a positive relationship to prevail between BTDs, as one of their tax aggressiveness' proxies, and institutional ownership.

Should the above-mentioned differences' positive implications predominate on average (e.g., Atwood and all. 2010; Desai and Dharmapala, 2009; Wilson, 2009; Hanlon and all, 2005), then a positive association is expected to persist between institutional ownership and BTDs. In effect, according to the above cited authors, the institutional investors' ratio is, the more power management will have to handle earnings upwardly, a situation which is likely to engender higher divergences between the accounting income and taxable one. In this respect, the following assumption can be proposed:

H5: A positive relationship predominates between institutional ownership and book-tax differences

\section{- Liquidity}

On studying the relationship between BTDs and liquidity, on the basis of a Croatian sample, Sodan (2012) has noted that the estimated results suggest well that liquidity proves to affect the difference between accounting and tax income. He judges his achieved finding by putting forward the following explanation "Companies with low values of this ratio are considered to potentially have liquidity problems and are more likely to perform earnings management. On the other hand, operating cash flow can also be seen as a component of company's net income. Thus, large income or large amounts of operating cash flow means that the company has to pay a high absolute amount of tax. Managers are willing to reduce this taxable base "Accordingly, the following hypothesis may well be postulated.

H6: Liquidity can well have an impact on book-tax differences.

\subsubsection{Alternative hypotheses: other factors influencing book- tax differences}

\section{- Size}

Several researchers, worth mentioning among whom are: Manzon and Plesko (2002), Mills and Newberry (2001) and Moore (2012) have not seemed to well identify the nature and sign of the relationship binding firm size and BTDs. Noteworthy, however, Mills (1998) has argued that, as large firms may have a wide range of resources for tax planning, it will be difficult for tax authorities to detect their non-complying behavior. Other researches tend to assume that small firms are more likely to use aggressive accounting policies to manage their income in a rising trend, thus highlight greater differences between the taxable income and the accounting one. This assumption proves to be based on the political cost advancing hypothesis, which argues that small businesses are more likely to resort to aggressive accounting methods for the sake of increasing reported income than large firms do (Watts and Zimmerman, 1990). As such, no prediction would be made with respect to this variable relative sign.

\section{- Leverage}

The leverage ratio designates an index reflecting company capital structure. As a matter of fact, two fund raising channels are available for companies can be distinguished, they are: the owners' investments collection, along with debt financing. In regard of debt financing, companies need to sign contracts with the lenders, in which certain restrictive turns and elements will be taken into account to ensure the creditors' interests. Indeed, several studies have appealed this ratio as a control variable useful for accounting-tax differences. In this context, Frank and all. (2009) have included this variable in the permanent differences' equation subject of their study. They have reached the finding that the previously conducted research has revealed that companies with relatively high debt levels have been enticed to manage their respective income in such a way as to avoid violating covenants (DeAngelo and all, 1994; Defond and Jiambalvo, 1994; Becker and all, 1998; Klein 2002). In this way, Watts and Zimmerman (1986) have noted well that the covenants' violation imposed by the leader turns out to be very costly to investors. They have also found that leaders, who are at the edge of violating these clauses, make accounting choices that could well reduce the likelihood of violating of such clauses. Thus, debt level can well be considered as a "Risk debts" proxy or rather "failure-related risks." Hence, highly leveraged firms often tend to exhibit greater information risk level, which would likely increase the implementation of earnings management practices. In other words, a high leverage may partly explain the earnings management outcome, and a subsequent increase in differences recorded between book income and the taxable one. So, one may well assume that a positive relationship does exist between the leverage level and BTDs.

- Lagged book-tax differences

This variable is introduced to serve a number of purposes. First, it has already been used as a control variable in several previously conducted studies to indicate the BTDs effects at time $t-1$ on the BTDs at time t. Second, as considered by Manzon and Plesko (2002), these variable stands as a noise factor with a positive effect on the level of differences between the book income and the taxable income. In their elaborated study, Frank and all, (2009) have included the lagged value of permanent BTDs as a means whereby to control non-discretionary permanents differences persistent over time (e.g., municipal bond interest and tax credits). Finally, the advantage brought about to the model estimation through introduction of the lag BTDs variable lies in ensuring a more effective evaluation of the model capacity to explain the studied phenomenon as well as an appreciation of the achieved results' stability. Therefore, it would sound logical for the following assumption to be exposed a positive relationship does prevail between lagged BTDs (at time t-1) and BTDs (at time t).

\section{Data and methodology}

\subsection{Data set explanation}

Our sample turns out to be ultimately made up of 28 Tunisian companies, after subtracting the companies belonging to the financial sector such as banks, financial institutions, insurance companies and investment firms (SICAF, SICAR and SICAV), as well as those companies regarding which no complete data has been obtained. Our empirical application covers an eight-year period, 
ranging from 2005 to 2012. For such an empirical application to be conducted, several data sources have been applied.

Table 1: Sample Constitution Procedure

\begin{tabular}{ll}
\multicolumn{2}{c}{ Table 1: Sample Constitution Procedure } \\
\hline Sample & $\begin{array}{l}\text { Number of } \\
\text { firms }\end{array}$ \\
\hline Initial sample & 77 \\
Firms belonging to financial industry & 47 \\
Firms with no complete data (missing, incomplete & 2 \\
prospectus) & 28 \\
Final sample & 28 \\
\hline
\end{tabular}

The listed companies' relevant data are collected from published financial statements as well as from official bulletins available from the prospectus found at the Financial Market Council of Tunis and on the BVMT and Thomson websites along with the Banker databases.

\subsection{Research methodology}

At this level, a multivariate specification is applied to investigate hypotheses 1 through 7, while accounting for additional factors likely to influence book-tax differences, as regressed on institutional and non-institutional determinants, along with several additional control variables. So, the estimated regression model is actually:

Model 1: without delayed variable BTDs

$$
\begin{aligned}
& \text { BTDs }_{\text {it }}=\beta_{0}+\beta_{1} \text { Profitability }_{\text {it }}+\beta_{2} \Delta \text { REV }_{\text {it }}+\beta_{3} \Delta \mathrm{INV}_{\text {it }} \\
& +\beta_{4} \text { DAAC }_{\text {it }}+\beta_{5} \text { PER }_{\text {it }}+\beta_{6} \text { InstOwn }_{\text {it }} \\
& +\beta_{7} \text { LIQ }_{\text {it }}+\beta_{8} \text { leverage }_{i t}+\beta_{9} \text { size }_{i t} \\
& +\varepsilon_{\text {it }} \text { model (1) }
\end{aligned}
$$

Model 2: with delayed variable BTDs

BTDs $_{\text {it }}=\beta_{0}+\beta_{1}$ Profitability $_{i t}+\beta_{2} \Delta$ REV $_{i t}+\beta_{3} \Delta \mathrm{INV}_{\text {it }}$ $+\beta_{4}$ DAAC $_{\text {it }}+\beta_{5}$ PER $_{\text {it }}+\beta_{6}$ InstOwn $_{\text {it }}$ $+\beta_{7}$ LIQ $_{\text {it }}+\beta_{8}$ leverage $_{i t}+\beta_{9}$ size $_{i t}$ $+\beta_{10}$ LagBTD $_{\text {it }}+\varepsilon_{\text {it }}$ model (2)

Where:

BTDs $_{\mathrm{it}}$ : the dependent variable is the sum of book-tax differences. Following most of the recently conducted researches (e.g., Ayers and al., 2010; Frank and al., 2009; Wilson, 2009; Dhaliwal and al., 2008; Desai and Dharmapala, 2006; Hanlon and al., 2005; Moore, 2012; Halon, 2012; Tang, 2014), total book-tax differences are defined as being a pretax financial statement income, less estimated than the taxable income, that can be inferred by dividing current tax expenses by tax rate. To note book-tax differences are scaled by average total assets for the cross-sectional size effect monitored.

Profitability $_{\text {it }}$ is a binary variable, taking on value one if the pretax income proves to be positive and zero otherwise; Sales growth $\left(\triangle \mathrm{REV}_{\mathrm{it}}\right)$ is calculated in the form of current year net sales as reported on the income statement minus prior year net sales scaled by total assets; Investment growth $\left(\Delta \mathrm{INV}_{\mathrm{it}}\right)$ is the investment change noticeable in gross property, plant and equipments from year $\mathrm{t}-1$ to year $\mathrm{t}$ scaled by total assets; $\mathrm{DACC}_{\mathrm{it}}$ discretionary accruals computed using the Raman and Shahrur $(2008)^{1} ; \mathrm{PER}_{\mathrm{it}}$ the price to earnings ratio is defined as being a share price divided by earnings per share relevant to year $\mathrm{t}$; $\mathrm{InstOwn}_{\text {it }}$ is the average percentage of firm i stock owned by institutional shareholders across all report dates for year $\mathrm{t}$; $\mathrm{LIQ}_{\mathrm{it}}$ is the ratio of total current assets and current liabilities for year $\mathrm{t}$; Size $_{\mathrm{it}}$ stands for the log total as-

\footnotetext{
${ }^{1}$ The Raman and Shahrur (2008) model is as follows : TAit/Ait-1 = $\mathbf{\alpha 0}$ $(1 /$ Ait-1) $+\alpha 1(\Delta$ REVit $-\Delta$ ARit $) /$ Ait-1 $+\alpha 2$ (PPEit/ Ait-1) $+\alpha 3$ ROAit-1 $+\alpha 4$ BTMit + eit Where for sample firm $i$ at time $t$, TAit represents the total accruals, Ait-1 the total assets, $\Delta$ REVit - $\Delta$ ARit the change in cash-basis revenue, PPEit the end of fiscal year gross property, plant, and equipment, ROAit-1 the is the return on equity ratio, BTMit the Book-to-market ratio and cit represents the error term which serves as proxy for discretionary accruals in year t. Finally, $\alpha \mathbf{0}, \alpha 1, \alpha 2, \alpha 3$ and $\alpha 4$ are parameter to be estimated.
}

sets with respect to year $t$; leverage $e_{i t}$ denotes the ratio of total debts and total assets regarding for year $\mathrm{t}$; LagBTDs $\mathrm{it}_{\mathrm{it}}$ represent the preceding year total book-tax differences scaled by total assets.

\section{Empirical results}

\subsection{Descriptive statistics and univariate analysis}

Table 2, below, reports the present research variables' descriptive statistics. The average book-tax difference level is $1.4 \%$ with minimum BTDs of $-30.7 \%$ and a maximum of $16.30 \%$. The discrepancy between the minimum and maximum values is considerably high, denoting large heterogeneity in firms' reporting gap.

Table 2: Descriptive statistic

\begin{tabular}{llllll}
\hline Variables & Obs & Average & Min & Max & Sdt.Dev. \\
\hline BTDs & 224 & 0.014 & -0.307 & 0.163 & 0.061 \\
$\Delta$ REV & 224 & 0.081 & -0.420 & 1.464 & 0.175 \\
$\Delta$ INV & 224 & 0.054 & -0.273 & 0.999 & 0.093 \\
DACC & 224 & -0.002 & -0.498 & 0.454 & 0.108 \\
LIQ & 224 & 2.17 & 0.360 & 10.95 & 1.784 \\
size & 224 & 7.869 & 6.726 & 9.20 & 0.436 \\
PER & 224 & 21.8 & -327.49 & 2485.5 & 176.0 \\
leverage & 224 & 0.411 & -0.200 & 14.080 & 1.378 \\
InstOwn & 224 & 0.310 & 0 & 0.999 & 0.275 \\
Profitability & & Freq. & Percentage & & Cum. \\
0 & & 42 & 18.83 & & 18.83 \\
1 & & 181 & 81.17 & & 100.00 \\
Total & 223 & 100.00 & & \\
\hline
\end{tabular}

BTD is calculated by determining the difference between pre-tax earnings and taxable income; Profitability is a binary variable, taking on value one if the pretax income is positive and zero otherwise; $\triangle \mathrm{REV}$ is calculated in terms of the current-year net sales as reported on the income statement minus the previous year net sales scaled by total assets; $\Delta \mathrm{INV}$ is the change in gross property, plant and equipments 'investment from year $\mathrm{t}-1$ to year $\mathrm{t}$ scaled by total assets; DACC discretionary accruals for firm $i$ at time $t$; PER the price to earnings ratio is defined as a price per share divided by earnings per share for year $t$; InstOwn is the average percentage of firm i stock owned by institutional shareholders across all report dates for year t; LIQ signifies the total current assets and liabilities ratio for year $t$; Size is log total assets for year $t$; Leverage denotes the ratio of total debts and total assets for year $\mathrm{t}$; Lag BTDs stand for total book-tax differences in the preceding year t-1 scaled by total assets. *, **, *** denote significant differences from zero at $0.10,0.05$ and 0.01 levels, respectively.

Table 2 depicts the major statistics pertaining to the independent variables. In terms of institutional factors, sales growths attain an average rate of $8.14 \%$, while investment growth proportion is of an order of $5.38 \%$ of total assets. Regarding the remaining variables included in the model, roughly $82 \%$ of the firms in the sample turn out to be profitable

With respect to non-institutional variables, the institutional ownership (InstOwn) pertinent statistics indicate that approximately $30.4 \%$ of the sample firms' stock is on average owned by institutions lying sited at the mean.

Noteworthy, also, the control variables' associated statistics include leverage and size bearing a mean of approximately $41 \%$ and $7.9 \%$ respectively.

The purpose lying behind implementing a univariate analysis consists in comparing the two group set characteristics: those pertaining to the group of firms featuring a high difference between both book and taxable incomes (BTDs located above the median $1.98 \%$ ) and those with low BTDs. Before undertaking the analysis, it appears that the independent variables' normality check seems imposed for the sake of choosing the appropriate statistical tests. In this particular context, the Kolmogorov-Smirnov test proves to be critically useful to apply for the purpose of evaluating the normality hypothesis with respect to our study relevant independent variables. Actually, it has been discovered that the entirety independent variables do not seem to follow a normal pattern. 
For these cases, we consider it useful to appeal to the U MannWhitney non-parametric test.

Table 3: Both Study Groups' Ddescriptive Statistics and Univarite Analysis Results

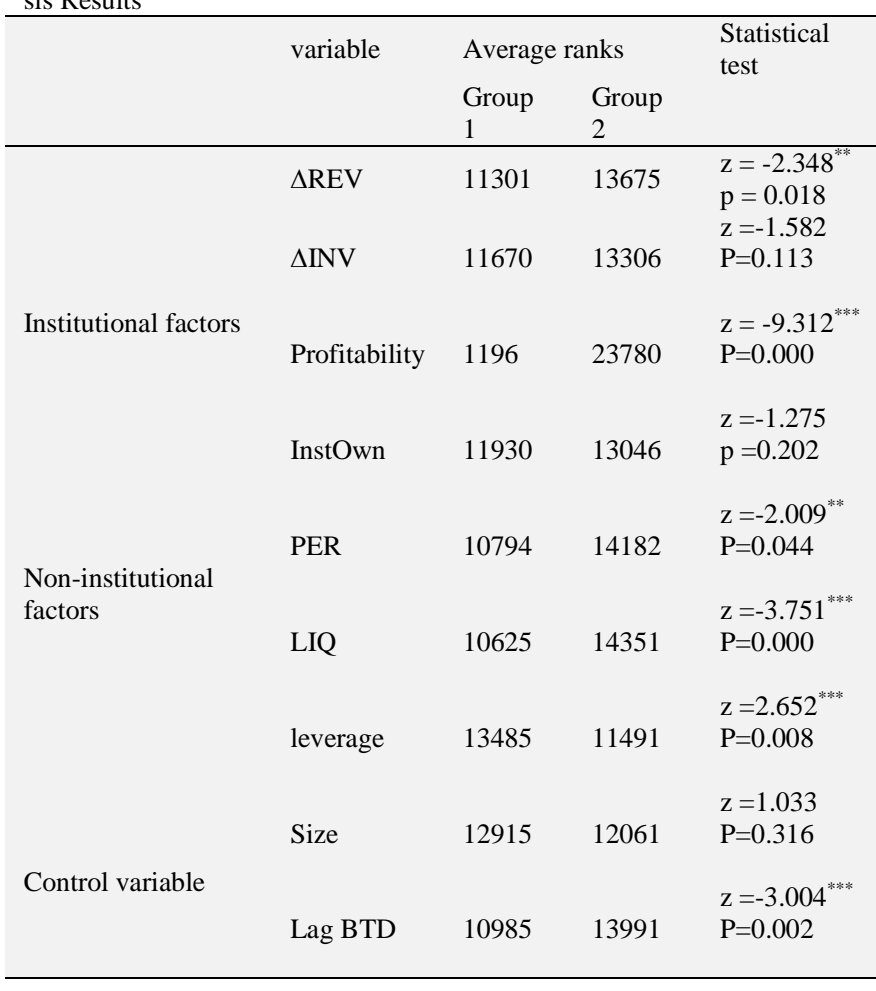

BTD is calculated by determining the difference between pre-tax earnings and taxable income; Profitability is a binary variable, taking on value one if the pretax income is positive and zero otherwise; $\triangle \mathrm{REV}$ is calculated in terms of the current-year net sales as reported on the income statement minus the previous year net sales scaled by total assets; $\Delta \mathrm{INV}$ is the change in gross property, plant and equipments 'investment from year $\mathrm{t}-1$ to year $\mathrm{t}$ scaled by total assets; DACC discretionary accruals for firm $i$ at time $t$; PER the price to earnings ratio is defined as a price per share divided by earnings per share for year $t$; InstOwn is the average percentage of firm i stock owned by institutional shareholders across all report dates for year $\mathrm{t}$; LIQ signifies the total current assets and lia- bilities ratio for year $\mathrm{t}$; Size is log total assets for year $\mathrm{t}$; Leverage denotes the ratio of total debts and total assets for year $\mathrm{t}$; Lag BTDs stand for total book-tax differences in the preceding year t-1 scaled by total assets. *, **, *** denote significant differences from zero at $0.10,0.05$ and 0.01 levels, respectively.

On examining table 3 , one may well note that the reached results indicate the persistence of remarkable differences between both groups sets with respect to: sales growth (Mann-Whitney U test, $\mathrm{p}$-value $=0.018)$, profitability $($ Mann-Whitney $\mathrm{U}$ test, $\mathrm{p}$-value $=$ 0.000 ), price to earnings ratio PER (Mann-Whitney U test, $p$-value $=0.044)$, liquidity $($ Mann-Whitney $\mathrm{U}$ test, $\mathrm{p}$-value $=0.000)$ and leverage (Mann-Whitney $U$ test, p-value $=0.008$ ). Noteworthy, however, no significant differences have been noticed to prevail among both sets regarding investment growth (Mann-Whitney U test, $\mathrm{p}$-value $=0.113$ ), institutional ownership (Mann-Whitney U test, $\mathrm{p}$-value $=0.202)$ and size $($ Mann-Whitney $\mathrm{U}$ test, $\mathrm{p}$-value $=$ $0.316)$.

Actually, the univariate analysis associated results do turn out to consolidate and support most of the already postulated hypotheses.

\subsection{Correlation analysis}

The correlation analysis pertinent results are reported on table 4 , highlighting that sales growth is positively correlated with the level of BTDs at $10 \%$ significance threshold, suggesting that highgrowth seeking firms are more likely to turn into rather volatile organization, with respect to certain dimensions (above all: profitability, cash flows, etc.) (Moore, 2012). Previously advanced evidence underlines well the predominance of a positive association between firm growth and BTDs (Manzon and Plesko, 2002), which harmoniously corroborates well the study second posed hypothesis. In addition, BTDs turn out to be positively and significantly correlated with profitability providing enough preliminary support for the first hypothesis. Besides, size is discovered to be negatively correlated with BTDs, confirming that small firms are more likely to appeal to aggressive accounting measures whereby to increase reported income than large firms. Actually do, such a result provides a first impression of the nature of relationship between lagged BTDs and BTDs. Thus, BTDs at t-1 prove to be positively and significantly correlated with the level of BTDs at $1 \%$ threshold.

Table 4: Correlation Matrix

\begin{tabular}{|c|c|c|c|c|c|c|c|c|c|c|c|c|}
\hline & BTDs & $\triangle \mathrm{REV}$ & $\Delta \mathrm{INV}$ & LIQ & SIZE & Profitability & PER & leverage & InstOwn & DACC & lagBTDs & VIF \\
\hline BTDs & 1 & & & & & & & & & & & \\
\hline$\triangle \mathrm{REV}$ & $\begin{array}{l}0.126 \\
0.060^{*}\end{array}$ & 1 & & & & & & & & & & 1.26 \\
\hline$\Delta \mathrm{INV}$ & $\begin{array}{l}0.082 \\
0.220\end{array}$ & $\begin{array}{l}0.336 \\
0.000^{* * *}\end{array}$ & 1 & & & & & & & & & 1.19 \\
\hline LIQ & $\begin{array}{l}0.232 \\
0.000^{\text {*** }}\end{array}$ & $\begin{array}{l}-0.161 \\
0.016^{* *}\end{array}$ & $\begin{array}{l}-0.058 \\
0.384\end{array}$ & 1 & & & & & & & & 1.52 \\
\hline Profitability & $\begin{array}{l}0.671 \\
0.000^{* * *}\end{array}$ & $\begin{array}{l}0.023 \\
0.731\end{array}$ & $\begin{array}{l}0.075 \\
0.262\end{array}$ & $\begin{array}{l}0.285 \\
0.000^{* * *}\end{array}$ & $\begin{array}{l}-0.105 \\
0.115\end{array}$ & 1 & & & & & & 1.23 \\
\hline PER & $\begin{array}{l}0.004 \\
0.951\end{array}$ & $\begin{array}{l}0.097 \\
0.157\end{array}$ & $\begin{array}{l}0.053 \\
0.440\end{array}$ & $\begin{array}{l}-0.015 \\
0.827\end{array}$ & $\begin{array}{l}0.072 \\
0.299\end{array}$ & $\begin{array}{l}0.153 \\
0.026^{* *}\end{array}$ & 1 & & & & & 1.05 \\
\hline leverage & $\begin{array}{l}-0.052 \\
0.440\end{array}$ & $\begin{array}{l}0.005 \\
0.937\end{array}$ & $\begin{array}{l}-0.031 \\
0.641\end{array}$ & $\begin{array}{l}-0.079 \\
0.242\end{array}$ & $\begin{array}{l}0.054 \\
0.424\end{array}$ & $\begin{array}{l}-0.211 \\
0.001 *\end{array}$ & $\begin{array}{l}-0.042 \\
0.547\end{array}$ & 1 & & & & 1.08 \\
\hline InstOwn & $\begin{array}{l}0.017 \\
0.800\end{array}$ & $\begin{array}{l}0.184 \\
0.05^{* *}\end{array}$ & $\begin{array}{l}0.035 \\
0.593\end{array}$ & $\begin{array}{l}-0.339 \\
0.000^{* * * *}\end{array}$ & $\begin{array}{l}0.174 \\
0.009^{* * *}\end{array}$ & $\begin{array}{l}-0.014 \\
0.830\end{array}$ & $\begin{array}{l}0.087 \\
0.205\end{array}$ & $\begin{array}{l}-0.088 \\
0.195\end{array}$ & 1 & & & 1.20 \\
\hline DACC & $\begin{array}{l}0.101 \\
0.131\end{array}$ & $\begin{array}{l}-0.029 \\
0.658\end{array}$ & $\begin{array}{l}-0.059 \\
0.377\end{array}$ & $\begin{array}{l}0.046 \\
0.486\end{array}$ & $\begin{array}{l}0.014 \\
0.828\end{array}$ & $\begin{array}{l}0.031 \\
0.636\end{array}$ & $\begin{array}{l}0.029 \\
0.671\end{array}$ & $\begin{array}{l}0.052 \\
0.443\end{array}$ & $\begin{array}{l}0.033 \\
0.619\end{array}$ & 1 & & 1.41 \\
\hline lagBTDs & $\begin{array}{l}0.412 \\
0.000^{* * *}\end{array}$ & $\begin{array}{l}0.078 \\
0.241\end{array}$ & $\begin{array}{l}-0.002 \\
0.972\end{array}$ & $\begin{array}{l}0.033 \\
0.619\end{array}$ & $\begin{array}{l}-0.036 \\
0.590\end{array}$ & $\begin{array}{l}0.156 \\
0.019^{* *}\end{array}$ & $\begin{array}{l}0.001 \\
0.986\end{array}$ & $\begin{array}{l}0.086 \\
0.201\end{array}$ & $\begin{array}{l}-0.003 \\
0.953\end{array}$ & $\begin{array}{l}0.553 \\
0.000^{* * * *}\end{array}$ & 1 & 1.46 \\
\hline
\end{tabular}

BTD is calculated by determining the difference between pre-tax earnings and taxable income; Profitability is a binary variable, taking on value one if the pretax income is positive and zero oth- erwise; $\triangle \mathrm{REV}$ is calculated in terms of the current-year net sales as reported on the income statement minus the previous year net sales scaled by total assets; $\Delta \mathrm{INV}$ is the change in gross property, 
plant and equipments 'investment from year $\mathrm{t}-1$ to year $\mathrm{t}$ scaled by total assets; DACC discretionary accruals for firm $i$ at time $t$; PER the price to earnings ratio is defined as a price per share divided by earnings per share for year $\mathrm{t}$; InstOwn is the average percentage of firm i stock owned by institutional shareholders across all report dates for year t; LIQ signifies the total current assets and liabilities ratio for year $\mathrm{t}$; Size is log total assets for year $\mathrm{t}$; Leverage denotes the ratio of total debts and total assets for year t; Lag BTDs stand for total book-tax differences in the preceding year t-1 scaled by total assets. *,**, *** denote significant differences from zero at $0.10,0.05$ and 0.01 levels, respectively.

Worth highlighting, what really matters most within a regression analysis framework lies in the persistence of a multi-collinearity problem among the independent variables. As can be noted from table 4, the entireties of correlation coefficients are discovered to be sited out placed below 0.8 thresholds, the limit at which a serious multi-collinearity problem stars to prevail. In addition, the variance inflation factors (VIFs) have been computed, stressing, in turn, the presence of colinearity phenomenon among the explanatory variables. Indeed, in all cases the VIFs are discovered to be set at below two levels a fact which leads us to deduce the absence of any multi-colinearity problems.
Table 5 reports the main regression results achieved with respect to model 1 and model 2 . Model 2 is estimated by including the variable lagBTDs derived from our study model (model 1). In fact, the model estimation advantage consists in allowing a better evaluation of the model capacity to explain the studied phenomenon along with an effective appreciation of the stability of the obtained results' stability. Indeed, at a $1 \%$ level, model one profitability proportion proves to be positively and significantly associated with BTDs, thus validating the already postulated hypothesis one. This fact suggests well that the profitable firms appear to have larger differences between taxable and book incomes than the loss registering firms, a finding which is consistent with those attained by Manzon and Plesko (2002), Tang and Firth (2011), Mills and Neweberry (2001) and Sodan (2012) reporting a positive relationship to persist between profitability and book-tax differences with regard to the USA, Chinese and Brazilian cases. Hence, it has been proven that with respect to the highly profitable firms, managers appear to seek to invest following the most appropriately beneficial tax framework, in such a way as to reduce the tax base, in a bid to enjoy and make the maximum profit from the tax benefit choices available to them and put at their disposal.

\subsection{Regression analysis}

Table 5: Linear Regression Results

\begin{tabular}{|c|c|c|c|c|}
\hline \multirow[b]{2}{*}{ Independent variables } & \multicolumn{2}{|c|}{ Model 1} & \multicolumn{2}{|c|}{ Model 2} \\
\hline & Coefficient & p-value & coefficient & $\mathrm{p}$-value \\
\hline \multicolumn{5}{|l|}{ Institutional factors } \\
\hline Profitability & 0.109 & $0.000^{* * *}$ & 0.100 & $0.000^{* * * *}$ \\
\hline$\triangle \mathrm{REV}$ & 0.045 & $0.017^{* *}$ & 0.029 & $0.087^{*}$ \\
\hline$\Delta \mathrm{INV}$ & 0.005 & 0.877 & 0.09 & 0.764 \\
\hline \multicolumn{5}{|c|}{ Non-institutionnal factors } \\
\hline DACC & 0.053 & $0.066^{*}$ & -0.052 & $0.092^{*}$ \\
\hline PER & $-3.9710^{-4}$ & $0.027^{* *}$ & -0.000 & $0.030^{* *}$ \\
\hline InsOwn & 0.004 & 0.682 & 0.008 & 0.415 \\
\hline LIQ & 0.002 & 0.320 & 0.002 & 0.185 \\
\hline \multicolumn{5}{|l|}{ Control variables } \\
\hline size & -0.004 & 0.594 & -0.003 & 0.666 \\
\hline leverage & 0.004 & $0.050^{* *}$ & 0.002 & 0.149 \\
\hline LagBTDs & - & - & 0.441 & $0.000^{* * *}$ \\
\hline $\mathrm{R}$-square & & 0.509 & & 0.590 \\
\hline Adj R-square & & 0.487 & & 0.569 \\
\hline Prob $>$ F & & $0.000^{* * * *}$ & & $0.000^{* * *}$ \\
\hline
\end{tabular}

BTD is calculated by determining the difference between pre-tax earnings and taxable income; Profitability is a binary variable, taking on value one if the pretax income is positive and zero otherwise; $\triangle \mathrm{REV}$ is calculated in terms of the current-year net sales as reported on the income statement minus the previous year net sales scaled by total assets; $\Delta \mathrm{INV}$ is the change in gross property, plant and equipments 'investment from year $\mathrm{t}-1$ to year $\mathrm{t}$ scaled by total assets; DACC discretionary accruals for firm $i$ at time $t$; PER the price to earnings ratio is defined as a price per share divided by earnings per share for year $t$; InstOwn is the average percentage of firm i stock owned by institutional shareholders across all report dates for year t; LIQ signifies the total current assets and liabilities ratio for year $t$; Size is log total assets for year $t$; Leverage denotes the ratio of total debts and total assets for year $\mathrm{t}$; Lag BTDs stand for total book-tax differences in the preceding year $\mathrm{t}-1$ scaled by total assets. $*, * *, * * *$ denote significant differences from zero at $0.10,0.05$ and 0.01 levels, respectively.

As a matter of fact, the hypothesis stipulating the persistence of a maintained relationship between sales growth $(\triangle \mathrm{REV})$ and BTDs has been clearly supported. Indeed, the coefficient attributed to this variable proves to be positive (at the threshold 0,017 ) and significant (at the 0.05 level), suggesting that growth seeking firms do actually apply a certain level of BTDs. This result is consistent with the findings reached by Manzon and Plesko (2002), Tang and Firth (2011), Kolay and al. (2011) and Moore (2012), stating that a turnover change distortion has actually been implemented by such firms, leading to differences between accounting and taxable income. Thus, with regard to the Tunisian particular context, this variable proves to yield negative accounting-tax differences due, mainly to differences noted in the determination of income and expenses by both accounting and tax systems. Furthermore, Kolay and all. (2011) Indicate, in their conducted study, that growth seeking firms may well be able to create a book-tax gap through adopting accrual methods to be implemented in their financial accounting statements. On the one hand, while reducing the taxable income through applying cash based methods, on the other.

According to table 5, the investment growth $(\triangle \mathrm{INV})$ coefficient seems to be not significant, thus inconsistent with our $\mathrm{H} 3$ anticipation as well as with the results achieved by Manzon and Plesko (2002) and Tang and Firth (2011) underlining a significantly positive relationship between investment growth and BTDs. In turn, Kolay and all. (2011) have also discovered that change in tangible assets helps give rise to temporary differences between the accounting income and the taxable one. Noteworthy, however, our achieved result turns out to be consistent with the finding of Moore (2012) reporting no significant relationship to prevail between investment growth and BTDs.

Regarding non-institutional factors, the regression results reveal that discretionary accruals (DAAC) do appear to positively affect BTDs $(\mathrm{P}=0.066)$. Such results prove to confirm well $\mathrm{H} 4$ within the threshold of $10 \%$, thus highlighting the earnings management practice positive effect on deviation between the book income and the tax one, harmoniously corroborating our preset predictions. Actually, these findings confirm well those attained by Tang and Firth (2011) and Tang (2005), in so far as these authors' studies, 
conducted to the Chinese context, have revealed that companies having included certain accounting manipulations in their incomes exhibit remarkable discrepancies on BTDs.

As expected, the regression results figuring on Table 5 reveal that the PER pertinent coefficient is negative $\left(-3.9710^{-4}\right)$ and significant (at the 0.05 level). Hypothesis 5 is, then, supported and this variable appears to have a significant impact on divergences between the book income and the taxable one. This result is consistent with Long and al. (2013) finding reached on exploring a negative and significant relationship between the price-to-earnings ratio and BTDs. In fact, they notice that once PE or PB turns out to be too high, the BTD amount will prove to be remarkably small too. In effect, the market would tend to believe that companies with large BTDs are marked with severe earnings manipulation thus allocating lower PER to firms.

As a matter of fact, our regression results appear to reveal that institutional ownership (InstOwn) does prove to have a positive though non-significant, effect on the BTDs level. Nevertheless, the estimated coefficient is discovered to be positive (0.004), hence, inconsistent with Moore (2012) finding, indicating the predominance of a significantly negative relationship between the institutional investors percentage and total BTDs. In fact, based on 7070 observations registered during 1998-2009, the authors' attained results suggest that, on average, firms with higher institutional ownership levels tend to score lower and less volatile differences. In other words, the institutional investors' remarkable persistence in capital ownership has been discovered to mitigate the managers' intense earnings manipulation extent.

With respect to the empirical results, they show that the variable liquidity (LIQ) sounds to have no significant effect on book-tax differences. In reality, this result seems to be inconsistent with Long and all. (2013) released results, highlighting the prevalence of a significantly negative relationship between liquidity and accounting-tax differences. Inversely, Sodan (2012) has found a significant relationship to prevail. He is demonstrated that companies with low values pertaining to this ratio are considered to be more liable to register potential liquidity problems and are, therefore, more likely to resort to practice earnings management manipulative distortions.

In regard of the control variables, table 5 indicates well that no significant relationship appears to predominate between company size and BTDs. Furthermore, one might all so notice that the estimated coefficient is obviously negative (-0.004), a finding which highly corroborates the assumptions already posed by Spengel and al. (2012) along with those advanced by Moore (2012). They assume that small firms appear to have a remarkable influence on BTDs, thus confirming the negative association between firm size and scaled BTDs.

The same table (table 5) also demonstrates the predominance of a statistically pronounced significant association (at the 0.05 level) that is positive at $(\mathrm{p}=0.05)$ level, between leverage and BTDs. These findings are inconsistent with our predicted expectation and the already elaborated preceding empirical studies. Moore (2012) and Long and all. (2013), for instance, have found that leverage is negatively and significantly correlated with differences between the book income and the taxable one. Concerning our particular context, one may well confirm that companies with a high debt level can partly provide an explanatory justification for earnings management manipulative practices and a subsequent increase in the differences distinguishing the book income and the taxable one.

Regarding model 2, the inclusion of lagBTDs founds to have no clear effect on the independent variables' significance. Still, their introduction into the model has helped modify adjusted $\mathrm{R}^{2}$, which seemed to range from 0.487 in regard of model 1 to 0.569 with respect to model 2. Furthermore, table 5 reveals also the presence of significant (at the 0.01 level) and positive $(\mathrm{p}=0.000)$ relationship between lagBTDs and total BTDs, denoting that differences between the book income and the taxable one occurring at time t- 1 do have an effect on time $t$ differences and help greatly in generating them.

\section{Conclusion}

It is worth mentioning that very few are those researchers who have undertaken to examine the issue of BTDs' pertaining deterministic factors (e.g., Manzon and Plesko, 2002; Mills and Newberry, 2001; Mills and Newberry, 2002; Tang and Firth, 2011). Noteworthy, however, Manzon and Plesko (2002) have conducted an investigation highlighting the major differences noticeable between book income and the taxable one. Actually, they identify four activities types likely to help affect book-tax income spread namely 1) demand controls for tax favored investment and financing action, 2) direct investment sources' related timing differences, 3) permanent differences and 4) noise factors.

With respect to the present study, a special examination of total BTDs relevant to the Tunisian context has been elaborated over the period 2005-2012, characterized by rising disconnection within the pertinent accounting-tax system, in a bid to provide extra evidence on the sources and magnitude of the reporting gap. In addition, a contribution has been made to explain the major institutional determinants standing as non-discretionary differences and non-institutional determinants likely to help identify the major discretionary discrepancies. The achieved empirical findings have appeared to support the predominance of a significantly positive impact of profitability on the BTDs' level, denoting, which implies that the profit-scoring firms turn out to be tend to record larger book-tax income differences than the loss-scoring one (Mills and Newberry, 2002). In addition, sales growth proves to be positively associated with differences registered between the book income and the taxable one. Indeed, growth recording firms may well appear to have more discretion in accounting procedures as compared to stable-revenue firms (Kolay and all, 2011). Noteworthy, however, the results seem to yield persistence of a positive relationship prevailing between investment growth and BTDs, though no significant association sounds to predominate. In fact, the study has not been able to provide evidence on whether liquidity firms do actually help add to widening the reporting gap.

As a matter of fact, results may well prove to have important implication on accounting standards setters whose main objective lies in reducing the extent of information asymmetry. Indeed, BTDs do play a remarkable role in informing not only the tax authorities but also external investors about the company actual financial situation. Indeed, if book-tax differences may well help to provide information to the market about the earnings management related issues, and then recording the BTDs may greatly participate in reducing the reported earnings' credibility (Halon and Heitzman, 2010).

A research line can be developed, namely, the examination of BTDs' transmitted information on earnings quality, through appreciation of these BTDs' information value, along with their content utility, for both shareholders and stakeholders.

\section{References}

[1] Atwood, T. J., Drake, M. S., \& Myers, L. A. (2010). Book-tax conformity, earnings persistence and the association between earnings and future cash flows. Journal of Accounting and Economics, 50(1), 111-125. http://dx.doi.org/10.1016/j.jacceco.2009.11.001.

[2] Ayers, B. C., Laplante, S. K., \&McGuire, S. T. (2010). Credit Ratings and Taxes: The Effect of Book-Tax Differences on Ratings Changes. Contemporary Accounting Research, 27(2), 359-402. http://dx.doi.org/10.1111/j.1911-3846.2010.01011.x.

[3] Beasley, M. S. (1996). An empirical analysis of the relation between the board of director composition and financial statement fraud. Accounting Review, 443-465.

[4] Beasley, M. S., Carcello, J. V., Hermanson, D. R., \&Lapides, P. D. (2000). Fraudulent financial reporting: Consideration of industry traits and corporate governance mechanisms. Accounting Horizons, 14(4), 441-454. http://dx.doi.org/10.2308/acch.2000.14.4.441.

[5] Becker, C. L., DeFond, M. L., Jiambalvo, J., \&Subramanyam, K. R (1998). The effect of audit quality on earnings management. Contemporary accounting research, 15(1), 1-24. http://dx.doi.org/10.1111/j.1911-3846.1998.tb00547.x. 
[6] Bouaziz Daoud, I., \& Ali Omri, M. (2011). Divergences comptabilitéfiscalité, gestion fiscale et gestion des résultats en Tunisie: les nouveaux défis. HAL.

[7] Bodie, Z., Kane, A., Marcus, A.J., 2005. Investments. Sixth ed McGraw Hill, New York.

[8] Chung, R., Firth, M., \& Kim, J. (2002). Institutional monitoring and opportunistic earnings management. Journal of Corporate $\mathrm{Fi}$ nance, 8(1), 29-48. http://dx.doi.org/10.1016/S0929-1199(01)00039-6.

[9] Comprix, J., Graham, R. C., \& Moore, J. A. (2011). Empirical evidence on the impact of book-tax differences on divergence of opinion among investors. Journal of the American Taxation Association, 33(1), 51-78. http://dx.doi.org/10.2308/jata.2011.33.1.51.

[10]Cornett, M. M., Marcus, A. J., \&Tehranian, H. (2008). Corporate governance and pay-for-performance: The impact of earnings management. Journal of Financial Economics, 87(2), 357-373. http://dx.doi.org/10.1016/j.jfineco.2007.03.003.

[11] DeAngelo, H., DeAngelo, L., \& Skinner, D. J. (1994). Accounting choice in troubled companies. Journal of accounting and economics, 17(1), 113-143. http://dx.doi.org/10.1016/0165-4101(94)90007$\underline{8}$.

[12]Dechow, P. M., Sloan, R. G., \& Sweeney, A. P. (1996). Causes and consequences of earnings manipulation: An analysis of firms subject to enforcement actions by the sec*. Contemporary accounting re search, 13(1), 1-36. $\quad$ http://dx.doi.org/10.1111/j.19113846.1996.tb00489.x.

[13]DeFond, M. L., \&Jiambalvo, J. (1994). Debt covenant violation and manipulation of accruals. Journal of accounting and econo mics, 17(1), 145-176. http://dx.doi.org/10.1016/0165-4101(94)900086.

[14]Desai, M. A., \&Dharmapala, D. (2006). Corporate tax avoidance and high-powered incentives. Journal of Financial Economics, 79(1), 145 179. http://dx.doi.org/10.1016/j.jfineco.2005.02.002.

[15]Desai, M. A., \&Dharmapala, D. (2009). Corporate tax avoidance and firm value. The Review of Economics and Statistics, 91(3), 537-546. http://dx.doi.org/10.1162/rest.91.3.537.

[16]Dhaliwal, D. S., Huber, R., Lee, H. S., \&Pincus, M. (2008). Book-tax differences, uncertainty about fundamentals and information quality, and cost of capital. Morton PK, Book-Tax Differences, Uncertainty about Fundamentals and Information Quality, and Cost of Capital (November 11, 2008). http://dx.doi.org/10.2139/ssrn.1127956.

[17]Dunbar, A., Phillips, J., \&Rego, S. O. (2004). The impact of the bonus depreciation rules on the ability of deferred tax expense and accrualbased measures to detect earnings management activities. In Proceedings. Annual Conference on Taxation and Minutes of the Annual Meeting of the National Tax Association (pp. 358-365). National Tax Association.

[18]Frank, M. M., Lynch, L. J., \&Rego, S. O. (2009). Tax reporting aggressiveness and its relation to aggressive financial reporting. The $A c$ counting Review, 84(2), http://dx.doi.org/10.2308/accr.2009.84.2.467.

[19]Goncharov, I., \& Werner, J. R. (2009). Reassessing the role of booktax conformity. Available at SSRN 975504.http://dx.doi.org/10.2139/ssrn.975504

[20]Graham, J. R., Raedy, J. S., \& Shackelford, D. A. (2012). Research in accounting for income taxes. Journal of Accounting and Econom ics, 53(1), 412-434.http://dx.doi.org/10.1016/j.jacceco.2011.11.006.

[21]Hanlon, M. (2005). The persistence and pricing of earnings, accruals and cash flows when firms have large book-tax differences. The Accounting Review, 80(1) 166.http://dx.doi.org/10.2308/accr.2005.80.1.137.

[22]Hanlon, M., Krishnan, G. V., \& Mills, L. F. (2012). Audit fees and book-tax differences. Journal of the American Taxation Association, 34(1), 55-86.http://dx.doi.org/10.2308/atax-10184.

[23]Hanlon, M., \&Heitzman, S. (2010). A review of tax research. Journal of Accounting and Economics, 50(2), 127 178.http://dx.doi.org/10.1016/j.jacceco.2010.09.002.

[24]Joos, P., Pratt, J., \& Young, S. (2003). Using deferred taxes to detect earnings management: Further evidence. Working Paper in M IT.

[25]Khurana, I. K., \& Moser, W. J. (2012). Institutional shareholders' investment horizons and tax avoidance. The Journal of the American Taxation Association, 35(1), 111-134.http://dx.doi.org/10.2308/atax$\underline{50315}$

[26]Khurana, I., \& Moser, W. (2009). Shareholder investment horizons and $\operatorname{tax}$ aggressiveness. Available at SSRN 1517913.http://dx.doi.org/10.2139/ssrn.1517913.

[27]Klein, A. (2002). Audit committee, board of director characteristics, and earnings management. Journal of accounting and econom ics, 33(3), 375-400.http://dx.doi.org/10.1016/S0165-4101(02)00059-9.

[28]Kolay, M., Schallheim, J., \& Wells, K. (2011). Do Non-Debt Tax Shields Matter for Debt Policy?University of Utah workingpaper.
[29]Lanis, R., \& Richardson, G. (2011). The effect of board of director composition on corporate tax aggressiveness. Journal of Accounting and Public Policy, 30(1), 5070.http://dx.doi.org/10.1016/j.jaccpubpol.2010.09.003

[30]Lev, B., \& Nissim, D. (2004). Taxable income, future earnings, and equity values. The Accounting Review, 79(4), 1039 1074.http://dx.doi.org/10.2308/accr.2004.79.4.1039.

[31]Long, Y. E., Ye, K., \& Lv, M. (2013). Non-institutional Determinants of Book-Tax Differences: Evidence from China. Journal of Accounting and Finance, 13(3), 147.

[32] Manzon, G. B., and G. A. Plesko. (2002). The relation between financial and tax reporting measures of income. The Law Review 55: 175214.

[33] Martani, D., Anwar, Y., Fitriasari, D. (2011). Book-Tax Gap: Evidence from Indonesia"; China-USA Business Review, 10 (4), 278-284.

[34] McGill, G. A., \& Outslay, E. (2004). Lost in translation: Detecting tax shelter activity in financial statements. National Tax Journal, 739756.

[35] McNichols M.F., (2002). Discussion of the Quality of Accruals and Earnings: The Role of Accrual Estimation Errors. The Accounting Review, Vol. 77(Supplement), pp. 6169.http://dx.doi.org/10.2308/accr.2002.77.s-1.61

[36] Mills, L. F. (1998). Book-tax differences and Internal Revenue Service adjustments. Journal of Accounting Research, 343 356.http://dx.doi.org/10.2307/2491481.

[37]Mills, L. F., Newberry, K. J., \&Novack, G. F. (2003). How well do Compustat NOL data identify firms with US tax return loss carryovers? Journal of the American Taxation Association, 25(2), 117.http://dx.doi.org/10.2308/jata.2003.25.2.1.

[38]Mills, L. F., Newberry, K. J., \&Trautman, W. B. (2002). Trends in book-tax income and balance sheet differences. Available at SSRN 313040.http://dx.doi.org/10.2139/ssrn.313040.

[39]Mills, L., \& Newberry, K. (2001). The influence of tax and non-tax costs on book-tax reporting differences: Public and private firms. Journal of the American Taxation Association, 23(1), 119.http://dx.doi.org/10.2308/jata.2001.23.1.1.

[40] Minnick, K., \&Noga, T. (2010). Do corporate governance characteristics influence tax management? Journal of Corporate Finance, 16(5), 703-718.http://dx.doi.org/10.1016/j.jcorpfin.2010.08.005.

[41] Molodovsky, N. (1953). A theory of price-earnings ratios. The Analysts Journal, 65-80.

[42]Monks, R., \&Minow, N. (1995). Corporate Governance Blackwell. Cambridge, MA

[43]Moore, J. A. (2012). Empirical evidence on the impact of external monitoring on book-tax differences. Advances in Accounting, 28(2), 254-269.http://dx.doi.org/10.1016/j.adiac.2012.06.002

[44]Lopo Martinez, A., Passamani, R., \& Teixeira, A. (2014). The Value Relevance of Book-Tax Differences in Brazil. Australian Journal of Basic \& Applied Sciences, 8(1)

[45]Phillips, J. D., Pincus, M., Rego, S. O., \& Wan, H. (2004). Decomposing changes in deferred tax assets and liabilities to isolate earnings management activities. Journal of the American Taxation Association, 26(s-1), 43-66.http://dx.doi.org/10.2308/jata.2004.26.s-1.43.

[46]Phillips, J., Pincus, M., \&Rego, S. O. (2003). Earnings management: New evidence based on deferred tax expense. The Accounting Review, 78(2), 491-521.http://dx.doi.org/10.2308/accr.2003.78.2.491.

[47]Plesko, G. A. (2000). Book-tax differences and the measurement of corporate income. In Proceedings. Annual Conference on Taxation and Minutes of the Annual Meeting of the National Tax Association (pp. 171-176). National Tax Association.

[48]Plesko, G. A., (2004). Corporate tax avoidance and the properties of corporate earnings. National Tax Journal, 729-737.

[49]Raman K. and Shahrur H., (2008). Relationship-specific investments and earnings management: Evidence on corporate suppliers and customers. The Accounting Review, Vol. 83(7), pp. 10411081.http://dx.doi.org/10.2308/accr.2008.83.4.1041.

[50]Seidman, J. K. (2010). Interpreting the book-tax income gap as earnings management or tax sheltering. McCombs Research Paper Series No. ACC-02-10.http://dx.doi.org/10.2139/ssrn.1564253.

[51]Shen, P. (2000). The P/E ratio and stock market performance. Economic Review-Federal Reserve Bank of Kansas City, 85(4), 23-36.

[52] Shevlin, T. (2001). Corporate tax shelters and book-tax differences. Tax L. Rev., 55, 427.

[53]Shleifer, A., \&Vishny, R. W. (1997). A survey of corporate governance. The journal of finance, 52(2), 737783.http://dx.doi.org/10.1111/j.1540-6261.1997.tb04820.x

[54]Sodan, S. (2012). Book-tax differences and companies' financial characteristics: The case of Croatia. The Business Review, Cambridge, 19 (2), 265-271 
[55]Tang, T. (2006). Book-tax differences: a function of accounting-tax misalignment, earnings management and tax management: empirical evidence from China. In American Accounting Association Annual Meeting, Washington DC

[56]Tang, T. (2014). Does Book-Tax Conformity Deter Opportunistic Book and Tax Reporting? An International Analysis. European Accounting Review, forthcoming.http://dx.doi.org/10.1080/09638180.2014.932297.

[57]Tang, T., \& Firth, M. (2011). Can book-tax differences capture earnings management and tax management? Empirical evidence from China. The International Journal of Accounting,46(2), 175204.http://dx.doi.org/10.1016/j.intacc.2011.04.005.

[58] Watts, R. L., \& Zimmerman, J. L. (1986); "Positive accounting theory". Englewood Cliffs.

[59]Watts, R. L., \& Zimmerman, J. L. (1990). Positive accounting theory: a ten year perspective. Accounting review, 131-156.

[60]Wilson, R. J. (2009). An examination of corporate tax shelter participants. The Accounting Review, 84(3), 969999.http://dx.doi.org/10.2308/accr.2009.84.3.969.

[61]Zinn, B., \&Spengel, C. (2012). Book-tax conformity: Empirical evidence from Germany (No. 12-051). ZEW Discussion Papers.http://dx.doi.org/10.2139/ssrn.2118569. 